\title{
PENERAPAN MODEL PEMBELAJARAN KOOPERATIF TIPE GROUP INVESTIGATION (GI) UNTUK MENINGKATKAN HASIL BELAJAR GEOGRAFI SISWA KELAS XI IPS SMA NEGERI 2 WAWOTOBI PADA MATERI POKOK SUMBER DAYA ALAM
}

\author{
Samrika Devi ${ }^{1}$ La Harudu ${ }^{2}$ \\ 1;2 Program Studi Pendidikan Geografi, Universitas Halu Oleo
}

\begin{abstract}
Abstrak: Penelitian Tindakan Kelas ini dilatar belakangi kurangnya keterlibatan siswa dalam kegiatan pembelajaran dan guru yang masih menggunakan metode ceramah dan mencatat buku. Penelitian ini bertujuan untuk mendeskripsikan aktivitas belajar siswa, aktivitas mengajar guru, dan hasil belajar geografi siswa yang diajarkan dengan menggunakan model pembelajaran kooperatif tipe Group Investigation (GI) pada materi pokok Sumber Daya Alam. Subyek penelitian ini adalah siswa kelas XI IPS SMA Negeri 2 Wawotobi T.A 2017/2018 yang berjumlah 30 orang. Penelitian dilaksanakan dalam dua siklus, yang terdiri dari tahap perencanaan, pelaksanaan, pengamatan, dan refleksi. Data dikumpulkan dari hasil observasi dan tes hasil belajar siswa. Hasil penelitian menunjukkan bahwa, aktivitas belajar siswa pada siklus I diperoleh skor rata-rata 2,6 dan meningkat menjadi 3,4 pada siklus II, aktivitas mengajar guru pada siklus I diperoleh skor rata-rata 2,6 dan meningkat menjadi 3,6 pada siklus II, untuk hasil belajar siswa pada siklus I diperoleh nilai rata-rata 74,27 dengan ketuntasan klasikal 70\%, dan pada siklus II terjadi peningkatan dengan nilai rata-rata 80,27 dengan persentase $83 \%$, hal ini menunjukkan bahwa melalui model kooperatif tipe Group Investigation hasil belajar Geografi siswa pada materi pokok Sumber Daya Alam dapat meningkat.
\end{abstract}

Kata Kunci : Aktivitas Belajar, Hasil Belajar, Group Investigation, dan Sumber Daya Alam 
Jurnal Penelitian Pendidikan Geografi Volume 3 No. 3 Juli 2018

\title{
APPLICATION OF COOPERATIVE LEARNING MODEL TYPE GROUP INVESTIGATION (GI) TO INCREASING LEARNIG RESULT OF GEOGRAPHIC STUDENT CLASS XI IPS SMA NEGERI 2 WAWOTOBI FOR NATURAL RESOURCES SUBJECT
}

\author{
Samrika Devi ${ }^{1}$ La Harudu ${ }^{2}$
}

\begin{abstract}
The Classroom Action Research is based on the lack of involvement of students in learning activities and teachers who still use lecture methods and record books. This study aims to describe student learning activities, teacher teaching activities, and students geography learning outcomes that are taught using cooperative learning model of Group Investigation (GI) on the subject matter of Natural Resources. The subject of this research is the students of class XI IPS SMA Negeri 2 Wawotobi T.A 2017/2018 which amounted to 30 people. The study was conducted in two cycles, consisting of planning, implementation, observation, and reflection. Data collected from the observation and test results of student learning. The results showed that, student learning activities on cycle I obtained an average score of 2.6 and increased to 3.4 on cycle II, teacher teaching activity on cycle I obtained an average score of 2.6 and increased to 3.6 on cycle II, for the students learning outcomes on cycle I obtained an average value of 74.27 with $70 \%$ classical completeness, and on cycle II an increase with an average value of 80.27 with $83 \%$ percentage, it shows that through the cooperative learning model of Group Investigation, the students geography learning outcomes on the subject matter of Natural Resources can be increased.
\end{abstract}

\section{Keyword : Learning Activities, Learning Outcomes, Group Investigation, and Natural Resources}

\section{PENDAHULUAN}

Dalam dunia pendidikan permasalahan selalu muncul bersamaan dengan berkembang dan meningkatnya kemampuan siswa, situasi dan kondisi lingkungan yang ada, pengaruh informasi dan kebudayaan, serta berkembangnya ilmu pengetahuan dan teknologi, sehingga peningkatan mutu pendidikan dewasa ini merupakan suatu kebutuhan yang perlu dilakukan penanganan secara menyeluruh. Kualitas pendidikan meliputi berbagai sektor dan jenjang pendidikan, termasuk jenjang pendidikan sekolah menengah.

Proses pembelajaran melibatkan banyak komponen yang saling terkait. Komponen-komponen pembelajaran tersebut harus mampu berinteraksi dan membentuk sistem yang saling berhubungan, sehingga mampu menciptakan proses pembelajaran yang berkualitas. Komponen pembelajran yang dimaksud antara lain tujuan pembelajaran, bahan pembelajaran, metode pembelajaran, media pembelajaran, guru dan pendidik, siswa, penilaian dan evaluasi (Suyanto dan Hisyam, 2000).

Berdasarkan observasi awal terhadap pembelajaran Geografi kelas XI IPS SMA Negeri 2 Wawotobi, permasalahan yang ditemukan yakni, kurangnya keterlibatan siswa dalam kegiatan pembelajaran. Siswa cenderung kurang berani untuk mengemukakan pendapat ataupun gagasan dalam pembelajaran, ketika guru mengajukan pertanyaan mengenai materi, hanya beberapa siswa saja yang menanggapi. Begitupun saat guru memberi kesempatan bertanya kepada siswa mengenai materi yang belum atau kurang dipahami, lebih banyak siswa yang diam saja, sehingga guru menganggap bahwa siswa telah memahami materi yang dijelaskan. Masalah lainnya yaitu dalam kegiatan belajar mengajar guru masih menggunakan metode pembelajaran ceramah dan mencatat buku. Akibatnya kemampuan siswa dalam menguasai materi cenderung kurang, sehingga berdampak 
pada rendahnya hasil belajar. Berikut hasil belajar Geografi siswa yang dicapai pada ulangan harian, khususnya pada materi pokok Sumber Daya Alam, dari 26 orang siswa kelas XI IPS SMA Negeri 2 Wawotobi T.A 2016/2017 hanya 11 orang siswa atau sebanyak $42,31 \%$ saja yang mencapai nilai Kriteria Ketuntasan Minimum (KKM) 70, dan 15 orang siswa lainnya atau sebanyak $57,69 \%$ belum mencapai nilai KKM dengan nilai rata-rata 48,52 (Dokumentasi nilai mata pelajaran Geografi, 2017).

Melihat kondisi pembelajaran tersebut, maka perlu adanya suatu tindakan untuk menerapkan suatu model pembelajaran yang diharapkan dapat meningkatkan hasil belajar siswa pada mata pelajaran Geografi. Salah satu model yang dapat digunakan dalam pembelajaran geografi model pembelajaran tipe Group Investigation (GI). Group investigation adalah model belajar kooperatif yang menempatkan siswa ke dalam kelompok secara heterogen dilihat dari perbedaan kemampuan dan latar belakang yang berbeda baik dari segi gender, etnik, dan agama untuk melakukan investigasi terhadap suatu topik (Eggen dan Kauchak dalam Harisantoso, 2005: 2)

Atas dasar itulah maka peneliti melakukan penelitian tentang "Penerapan Model Pembelajaran Kooperatif Tipe Group Investigation (GI) Untuk Meningkatkan Hasil Belajar Geografi Siswa Kelas XI IPS SMA Negeri 2 Wawotobi pada Materi Pokok Sumber Daya Alam".

Slameto (2003: 2) menyatakan belajar adalah suatu proses usaha yang dilakukan seseorang untuk memperoleh suatu perubahan tingkah laku yang baru secara keseluruhan, sebagai hasil pengalamannya sendiri dalam interaksi dengan lingkungannya.

Menurut Trianto (2010: 17) pembelajaran merupakan aspek kegiatan manusia yang kompleks, yang tidak sepenuhnya dapat dijelaskan. Pembelajaran secara simple dapat diartikan sbagai produk interaksi antara pengembangan dan pengalaman hidup. Pembelajaran dalam makna kompleks adala usaha sadar dari seorang guru untuk membelajarkan siswanya (mengarah interksi siswa dengan sumber belajar lainnya) dalam rangka mencapai tujuan yang diharapkan.

Pembelajaran yang efektif adalah pembelajaran yang menyediakan kesempatan belajar sendiri atau melakukan aktivitas sendiri. Proses pembelajaran yang dilakukan di dalam kelas merupakan aktivitas mentransformasikan pengetahuan, sikap, dan ketrampilan (Martinis Yamin, 2007: 75). Aktivitas merupakan prinsip atau asas yang sangat penting dalam interaksi belajar mengajar (Sardiman, 2006: 96).

Oemar Hamalik (2009: 179) menyatakan bahwa aktivitas belajar merupakan kegiatan yang dilakukan oleh siswa dalam kegiatan pembelajaran.

Hasil belajar tampak sebagai terjadinya perubahan tingkah laku pada diri siswa, yang dapat diamati dan diukur dalam bentuk perubahan pengetahuan, sikap dan keterampilan. Perubahan tersebut dapat diartikan terjadinya peningkatan dan pengembangan yang lebih baik dibandingkan dengan sebelumnya, misalnya dari tidak tahu menjadi tahu, sikap kurang sopan menjadi sopan, dan sebagainya (Oemar Hamalik, 2009: 155).

Dimyati dan Mudjiono (2006: 3) juga menyebutkan hasil belajar merupakan hasil dari suatu interaksi tindak belajar dan tindak mengajar. Dari sisi guru, tindak mengajar diakhiri dengan proses evaluasi hasil belajar. Dari sisi siswa, hasil belajar merupakan berakhirnya pengajaran dari puncak proses belajar.

Menurut Rifa'i (2009: 85) hasil belajar merupakan perubahan perilaku yang diperoleh peserta didik setelah mengalami kegiatan belajar.

Menurut Ferdinan Von Ricthoffen dalam Gatot Harmanto (2008: 5) bahwa geografi adalah suatu studi tentang gejala dan sifat-sifat permukaan bumi serta penduduknya yang disusun berdasarkan letak dan mencoba menjelaskan interaksi antara gejala dan sifat-sifat itu.

Ada dua aspek utama yang dipelajari dalam geografi yakni aspek 
lingkungan fisik dan aspek lingkungan sosial. Aspek lingkungan fisik menyangkut keadaan lingkungan alam di luar manusia, seperti bentuk muka bumi, perairan, keadaan udara, dunia tumbuhan dan hewan. Aspek lingkungan sosial mencangkup permasalahan yang berhubungan dengan aktivitas manusia sebagai makhluk sosial, yang tercermin dari budayanya (Khosim dan Lubis, 2007: 6).

Menurut Wina Sanjaya (2010: 242) pembelajaran kooperatif merupakan model pembelajaran dengan menggunakan sistem pengelompokan/tim kecil, yaitu antara empat sampai enam orang yang mempunyai latar belakang kemampuan akademik, jenis kelamin, ras, atau suku yang berbeda (heterogen). Sistem penilaian dilakukan terhadap kelompok. Setiap kelompok akan memperoleh penghargaan (reward), jika kelompok mampu menunjukkan prestasi yang dipersyaratkan. Dengan demikian, setiap anggota kelompok akan mempunyai ketergantungan positif. Ketergantungan itulah yang selanjutnya akan memunculkan tanggung jawab individu terhadap kelompok dan keterampilan interpersonal dari setiap anggota kelompok. Setiap individu akan saling membantu, mereka akan mempunyai motivasi untuk keberhasilan kelompok, sehingga setiap individu akan memiliki kesempatan yang sama untuk memberikan kontribusi demi keberhasilan kelompok.

Group Investigation berasal dari kata "Group" yang artinya kelompok dan "Investigation" yang artinya mencari dan menemukan, sehingga model pembelajaran Group Investigationdapat didefenisikan sebagai suatu model pengajaran yang bersifat kelompok dimana siswa tidak hanya bekerja sama namun terlihat merencanakan baik topik untuk dipelajari dan prosedur penyidikan yang akan digunakan (Ibrahim, 2000: 24).

Putra (2009: 2) mengemukakan bahwa model pembelajaran Group Investigation (GI) atau investigasi kelompok telah digunakan dalam berbagai bidang studi dan dan berbagai tingkat usia. Pada dasarnya model ini dirancang untung membimbing para siswa mendefinisikan masalah, mengeksplorasi berbagai cakrawala mengenai masalah itu, mengumpulkan data yang relevan,mengembangkannya dan mengetes hipotesis.

Model pembelajaran tipe Group Investigation ini pertama kali dikembangkan oleh Thelen, kemudian diperluas oleh Sharan dkk di Universitas Tel Aviv, dan merupakan pembelajaran paling kompleks. Dalam pendekatan ini siswa dituntut lebih berkreaktif dalam melakukan kerja sama dalam kelompok yang telah dibagi oleh guru menjadi 5 atau 6 anggota dalam kelompok yang heterogen. Siswa memilih topik apa yang akan diselidiki serta melakukan penyidikan yang mendalam terhadap topik yang yang telah dipilihnya (Nurhadi, 2004).

\section{METODE PENELITIAN}

Penelitian ini dilaksanakan pada Semester Ganjil Tahun Ajaran 2017/2018, mulai tanggal 18 Oktober s/d 2 November 2017 pada kelas XI IPS SMA Negeri 2 Wawotobi. Subyek penelitian ini adalah siswa kelas XI IPS SMA Negeri 2 Wawotobi yang terdaftar pada Semester Ganjil Tahun Ajaran 2017/2018, yang berjumlah 30 orang terdiri dari 18 orang siswa laki-laki dan 12 orang siswa perempuan. Faktor-faktor yang diteliti dalam penelitian tindakan kelas ini adalah: 1) Faktor siswa 2) Faktor guru 3) Faktor hasil belajar. Penelitian tindakan kelas ini terdiri 4 tahap, yakni: perencanaan, pelaksanaan tindakan, pengamatan (observasi), dan refleksi. Instrumen penelitian ini terdiri atas tiga jenis, yaitu: 1) lembar observasi aktivitas siswa, 2) lembar observasi untuk memperoleh data aktivitas guru, 3) tes siklus .

Data dikumpulkan berdasarkan hasil tindakan yang dilakukan pada proses observasi, proses belajar-mengajar, tes hasil belajar, dan refleksi. Selanjutnya data dianalisis menggunakan analisis deskripstif kualitatif dan deskripstif kuantitatif. Analisis deskriptif kualitatif digunakan 
untuk memberikan penjelasan mengenai aktivitas siswa serta kemampuan guru selama proses pembelajaran berlangsung. Sedangkan analisis deskriptif kuantitatif digunakan untuk menyajikan presentase aktivitas guru dalam mengelola pembelajaran, presentase aktivitas siswa dan presentase ketuntasan hasil belajar siswa.

\section{Menentukan hasil belajar siswa secara individual}

Dalam menentukan niai hasil belajar siswa dapat menggunakan rumus :

$$
X i=\frac{S p i}{S m} x 100
$$

(Usman dan Setiawati, 2001)

Keterangan:

$X \mathrm{i}=$ nilai yang diperoleh siswa ke-i

Spi = skor yang diperoleh siswa ke-i

$\mathrm{Sm}=$ skor maksimal

\section{Menentukan niai rata-rata hasil belajar} siswa

(Sudjana, 2005)

$$
\bar{X}=\frac{\sum X_{i}}{N}
$$

Keterangan:

$\bar{X} \quad=$ nilai rata - rata yang diperoleh

siswa

$\sum \mathrm{Xi}=$ nilai yang diperoleh tiap siswa
$\mathrm{N}=$ jumlah siswa secara keseluruhan

Menentukan tingkat pencapaian ketuntasan belajar secara klasikal

$$
\% \text { Tuntas }=\frac{\sum T B}{N} \mathrm{X} 100 \%
$$

(Sudjana, 2005)

Keterangan:

$\sum_{\mathrm{TB}}=$ jumlah siswa yang tuntas belajar

$\mathrm{N} \quad=$ jumlah siswa secara keseluruhan

\section{Mengklasifikasikan skor rata-rata aktivitas belajar siswa dan aktivitas mengajar guru}

$1 \leq \mathrm{Xi}<2 \quad$ : Kategori Kurang

$2 \leq \mathrm{Xi}<3 \quad$ : Kategori Cukup

$3 \leq \mathrm{Xi}<4 \quad$ : Kategori Baik

$\mathrm{Xi}=4 \quad$ : Kategori Sangat Baik

(Susetyo, 2010)

\section{HASIL PENELITIAN}

\section{Pelaksanaan Tindakan Siklus I}

Aktivitas Belajar Siswa Siklus I

Berikut data aktivitas belajar siswa yang diajar dengan menerapkan model pembelajaran Group Investigation pada siklus I.

Tabel 3.1. Data Aktivitas Belajar Siswa Siklus

\begin{tabular}{llccc}
\hline \multirow{2}{*}{ No } & \multicolumn{1}{c}{ Aspek yang diamati } & \multicolumn{3}{c}{ Siklus I } \\
\cline { 3 - 5 } 1 & $\begin{array}{l}\text { Siswa mendengarkan tujuan/kompetensi } \\
\text { pembelajaran yang ingin dicapai. }\end{array}$ & 2,6 & 2,6 & $\mathbf{2 , 6}$ \\
\hline \multirow{2}{*}{2} & $\begin{array}{l}\text { Siswa memfokuskan pikiran pada satu pokok } \\
\text { materi/bahasan yang ingin di bahas dan menjawab } \\
\text { pertanyaan guru. }\end{array}$ & 2,4 & 2,8 & $\mathbf{2 , 6}$ \\
\hline 3 & Siswa membentuk kelompok yang heterogen & 3,6 & 3,6 & $\mathbf{3 , 6}$ \\
\hline 4 & $\begin{array}{l}\text { Siswa menerima LKS dan mendiskusikan secara } \\
\text { kelompok langkah-langkah penyelidikan terkait } \\
\text { masalah yang disajikan dalam LKS }\end{array}$ & 2,6 & 2,6 & $\mathbf{2 , 6}$ \\
\hline 5 & $\begin{array}{l}\text { Siswa berfantasi mengumpulkan, menganalisis dan } \\
\text { mengevaluasi informasi }\end{array}$ & 2 & 2,8 & $\mathbf{2 , 4}$ \\
\hline
\end{tabular}


Jurnal Penelitian Pendidikan Geografi Volume 3 No. 3 Juli 2018

\begin{tabular}{clccc}
\hline 6 & $\begin{array}{l}\text { Siswa bekerja sama dalam mempersiapkan laporan } \\
\text { akhir yang akan dipersentasekan didepan kelas. }\end{array}$ & 2 & 2,4 & $\mathbf{2 , 2}$ \\
\hline 7 & $\begin{array}{l}\text { Siswa bekerja sama dalam memepersentasekan } \\
\text { hasil kerjanya dan kelompok lain memberikan } \\
\text { anggapan. }\end{array}$ & 2 & 3 & $\mathbf{2 , 5}$ \\
\hline 8 & $\begin{array}{l}\text { Siswa bertanya mengenai materi yang belum atau } \\
\text { kurang dipahami }\end{array}$ & 2,4 & 2,8 & $\mathbf{2 , 6}$ \\
\hline 9 & $\begin{array}{l}\text { Siswa bekerja sama menyimpulkan materi } \\
\text { pembelajaran }\end{array}$ & 2,4 & 2,6 & $\mathbf{2 , 5}$ \\
\hline 10 & $\begin{array}{l}\text { Siswa mendengarkan informasi mengenai } \\
\text { pembelajaran yang akan dipelajari pada pertemuan } \\
\text { selanjutnya }\end{array}$ & 2,6 & 2,8 & $\mathbf{2 , 7}$ \\
\hline & Rata-rata aktivitas belajar siswa & 2,5 & 2,8 & $\mathbf{2 . 6}$ \\
\hline$\quad$ Kategori & & & $\mathbf{C u k u p}$ \\
\hline
\end{tabular}

Sumber: Analisis Data (2017)

Tabel 3.1 diatas menunjukkan bahwa skor rata-rata aktivitas belajar siswa pada siklus I selama dua kali pertemuan termasuk dalam kategori cukup yaitu sebesar 2,6.

\section{Aktivitas Mengajar Guru Siklus I}

Berikut data hasil analisis aktivitas mengajar guru dengan menerapkan model pembelajaran Group Investigation pada siklus I.

Tabel 3.2 Data Aktivitas Mengajar Guru Siklus I

\begin{tabular}{|c|c|c|c|c|}
\hline \multirow{2}{*}{ No } & \multirow[b]{2}{*}{ Aspek Yang Diamati } & \multicolumn{3}{|c|}{ Siklus I } \\
\hline & & Pert. I & Pert. II & Rata-rata \\
\hline \multicolumn{5}{|c|}{ Kegiatan awal } \\
\hline 1 & $\begin{array}{l}\text { Guru membuka pelajaran memberi salam dan doa } \\
\text { sebelum memulai pelajaran. }\end{array}$ & 3 & 3 & 3 \\
\hline 2 & Guru mengecek kehadiran siswa. & 3 & 3 & 3 \\
\hline 3 & $\begin{array}{l}\text { Guru memberikan motivasi dan apersepsi kepada } \\
\text { siswa. }\end{array}$ & 2 & 3 & 2,5 \\
\hline 4 & Guru menyampaikan tujuan pembelajaran. & 3 & 3 & 3 \\
\hline \multicolumn{5}{|c|}{ Kegiatan inti } \\
\hline 5 & $\begin{array}{l}\text { Guru menyampaikan sub topik pembelajaran yang } \\
\text { akan diselidiki }\end{array}$ & 2 & 3 & 2,5 \\
\hline 6 & $\begin{array}{l}\text { Guru membagi kelas dalam beberapa kelompok } \\
\text { heterogen beranggotakan } 4-5 \text { orang siswa }\end{array}$ & 3 & 4 & 3,5 \\
\hline 7 & $\begin{array}{l}\text { Guru membagikan LKS kepada setiap kelompok } \\
\text { kelompok serta mempersiapkan dan menata } \\
\text { sumber belajar lain sebagai sarana siswa berfantasi } \\
\text { agar dapat berinvestigasi secara optimal. }\end{array}$ & 3 & 3 & 3 \\
\hline 8 & $\begin{array}{l}\text { Guru memfasilitasi, membimbing serta mengawasi } \\
\text { siswa yang sedang berfantasi dan berinvestigasi } \\
\text { agar setiap kelompok dapat bekerja optimal. }\end{array}$ & 2 & 3 & 2,5 \\
\hline 9 & $\begin{array}{l}\text { Guru membimbing tiap kelompok untuk } \\
\text { mempersiapakan laporan akhir yang akan } \\
\text { dipersentasekan didepan kelas. }\end{array}$ & 3 & 3 & 3 \\
\hline
\end{tabular}




\begin{tabular}{|c|c|c|c|c|}
\hline 10 & $\begin{array}{l}\text { Guru meminta setiap kelompok untuk } \\
\text { mempersentasikan laporan akhir kelompoknya } \\
\text { didepan kelas dan kelompok lainnya diminta untuk } \\
\text { memperhatikan jalannya persentasi, membuat } \\
\text { rangkuman, dan/atau mengajukan pertanyaan } \\
\text { terkait topik yang disajikan. }\end{array}$ & 2 & 2 & 2 \\
\hline 11 & $\begin{array}{l}\text { Guru memberikan penghargaan kepada kelompok } \\
\text { yang kinerjanya bagus dan memberikan motivasi } \\
\text { pada kelompok yang kurang baik. }\end{array}$ & 1 & 2 & 1,5 \\
\hline 12 & $\begin{array}{l}\text { Guru memberikan penegasan terhadap masing- } \\
\text { masing bahasan dari setiap kelompok. }\end{array}$ & 3 & 3 & 3 \\
\hline 13 & $\begin{array}{l}\text { Guru melakukan refleksi terhadap pembelajaran } \\
\text { yang telah dipelajari. }\end{array}$ & 1 & 2 & 1,5 \\
\hline \multicolumn{5}{|c|}{ Kegiatan akhir } \\
\hline 14 & $\begin{array}{l}\text { Guru memberikan kesempatan kepada siswa untuk } \\
\text { bertanya mengenai materi yang kurang dimengerti }\end{array}$ & 2 & 2 & 2 \\
\hline 15 & $\begin{array}{l}\text { Guru bersama siswa menyimpulkan materi yang } \\
\text { telah dibahas }\end{array}$ & 3 & 3 & 3 \\
\hline 16 & $\begin{array}{l}\text { Guru memberi tugas kepada siswa terkait dengan } \\
\text { materi yang sudah dipelajari }\end{array}$ & 2 & 3 & 2,5 \\
\hline 17 & $\begin{array}{l}\text { Guru menyampaikan bahwa pada } \\
\text { pertemuberikutnya masih menggunakan metode } \\
\text { yang sama }\end{array}$ & 2 & 2 & 2 \\
\hline 18 & $\begin{array}{l}\text { Guru menutup kegiatan pembelajaran dengan } \\
\text { salam }\end{array}$ & 3 & 3 & 3 \\
\hline & Rata Rata Aktivitas Mengajar Guru & 2.4 & 2.8 & 2.6 \\
\hline \multicolumn{2}{|r|}{ Kategori } & & & Cukup \\
\hline
\end{tabular}

Sumber: Analisis Data (2017)

Tabel 3.2 diatas menunjukkan bahwa skor rata-rata aktivitas mengajar guru pada siklus I selama dua kali pertemuan termasuk dalam kategori cukup yaitu 2,6.

\section{Hasil Belajar Siswa Siklus I}

Berdasarkan analisis hasil belajar siswa pada siklus I diperoleh data sebagai berikut:

Tabel 3.3 Perolehan Nilai Hasil Belajar Siswa Pada Siklus I

\begin{tabular}{lc}
\multicolumn{1}{c}{ Hasil Belajar } & Nilai \\
\hline Nilai Tertinggi & 92 \\
\hline Nilai Terendah & 40 \\
\hline Rata-rata & 74,27
\end{tabular}

Sumber: Analisis Data (2017)

Tabel 3.3 diatas menunjukkan hasil belajar siswa kelas XI IPS pada siklus I yang diajar dengan menggunakan model pembelajaran Group Investigation dengan perolehan nilai tertinggi sebesar 92, nilai terendah 40, dan nilai rata-rata 74,27.
Selanjutnya data dianalisis berdasarkan ketuntasan belajar siswa, dengan hasil sebagai berikut: 
Jurnal Penelitian Pendidikan Geografi Volume 3 No. 3 Juli 2018

Tabel 3.4 Deskripsi Ketuntasan Belajar Siswa Siklus I

\section{$\begin{array}{lll}\text { Ketuntasan } & \text { Jumlah Siswa (orang) } & \text { Persentase (\%) }\end{array}$}

\begin{tabular}{lcc}
\hline Sudah Tuntas & 21 & 70 \\
\hline Belum Tuntas & 9 & 30 \\
\hline Jumlah & $\mathbf{3 0}$ & $\mathbf{1 0 0}$ \\
\hline
\end{tabular}

Sumber: Analisis Data (2017)

Tabel 3.4 diatas menunjukkan ketuntasan belajar siswa pada siklus I, dengan siswa yang memperoleh nilai ketuntasan sebanyak 21 orang atau sekitar $70 \%$, dan siswa yang belum memperoleh nilai ketuntasan sebanyak 9 orang atau sekitar $30 \%$. Hal tersebut menunjukkan bahwa hasil belajar siswa pada siklus I

belum memenuhi indikator keberhasilan yakni $\geq 80 \%$.

Pelaksanaan Tindakan Siklus II

\section{Aktivitas Belajar Siswa Siklus II}

Berikut data aktivitas belajar siswa yang diajar dengan menerapkan model pembelajaran Group Investigation pada siklus II.

Tabel 3.5 Data Aktivitas Belajar Siswa Siklus II

\begin{tabular}{|c|c|c|c|c|}
\hline \multirow[b]{2}{*}{ No } & \multirow[b]{2}{*}{ Aspek yang diamati } & \multicolumn{3}{|c|}{ Siklus II } \\
\hline & & Pert. I & Pert. II & Rata-rata \\
\hline 1. & $\begin{array}{l}\text { Siswa mendengarkan tujuan/kompetensi } \\
\text { pembelajaran yang ingin dicapai. }\end{array}$ & 3,2 & 3,4 & 3,3 \\
\hline 2. & $\begin{array}{l}\text { Siswa memfokuskan pikiran pada satu pokok } \\
\text { materi/bahasan yang ingin di bahas dan menjawab } \\
\text { pertanyaan guru. }\end{array}$ & 3,2 & 3,4 & 3,3 \\
\hline 3. & Siswa membentuk kelompok yang heterogen & 4 & 4 & 4 \\
\hline 4. & $\begin{array}{l}\text { Siswa menerima LKS dan mendiskusikan secara } \\
\text { kelompok langkah-langkah penyelidikan terkait } \\
\text { masalah yang disajikan dalam LKS }\end{array}$ & 3,4 & 3,2 & 3,3 \\
\hline 5. & $\begin{array}{l}\text { Siswa berfantasi mengumpulkan, menganalisis dan } \\
\text { mengevaluasi informasi }\end{array}$ & 3 & 3,4 & 3,2 \\
\hline 6. & $\begin{array}{l}\text { Siswa bekerja sama dalam mempersiapkan laporan } \\
\text { akhir yang akan dipersentasekan didepan kelas. }\end{array}$ & 3 & 3,6 & 3,3 \\
\hline 7. & $\begin{array}{l}\text { Siswa bekerja sama dalam memepersentasekan } \\
\text { hasil kerjanya dan kelompok lain memberikan } \\
\text { tanggapan. }\end{array}$ & 3,2 & 3,2 & 3,2 \\
\hline 8. & $\begin{array}{l}\text { Siswa bertanya mengenai materi yang belum atau } \\
\text { kurang dipahami }\end{array}$ & 3 & 3,2 & 3,1 \\
\hline 9. & $\begin{array}{l}\text { Siswa bekerja sama menyimpulkan materi } \\
\text { pembelajaran }\end{array}$ & 3,2 & 3,4 & 3,3 \\
\hline 10. & $\begin{array}{l}\text { Siswa mendengarkan informasi mengenai } \\
\text { pembelajaran yang akan dipelajari pada pertemuan } \\
\text { selanjutnya }\end{array}$ & 3,4 & 3,8 & 3,6 \\
\hline & Rata-rata aktivitas belajar siswa & 3,3 & 3,5 & 3,4 \\
\hline & Kategori & & & Baik \\
\hline
\end{tabular}

Sumber: Analisis Data (2017) 
Berdasarkan data pada tabel 3.5 terlihat bahwa aktivitas belajar siswa pada siklus II mengalami peningkatan. Hal ini ditunjukkan oleh skor rata-rata aktivitas belajar siswa yang mencapai 3,4 dengan kategori baik.
Gambaran mengenai peningkatan rata-rata aktivitas belajar siswa selama pembelajaran pada siklus I dan siklus II dapat dilihat pada Gambar 3.1 berikut:

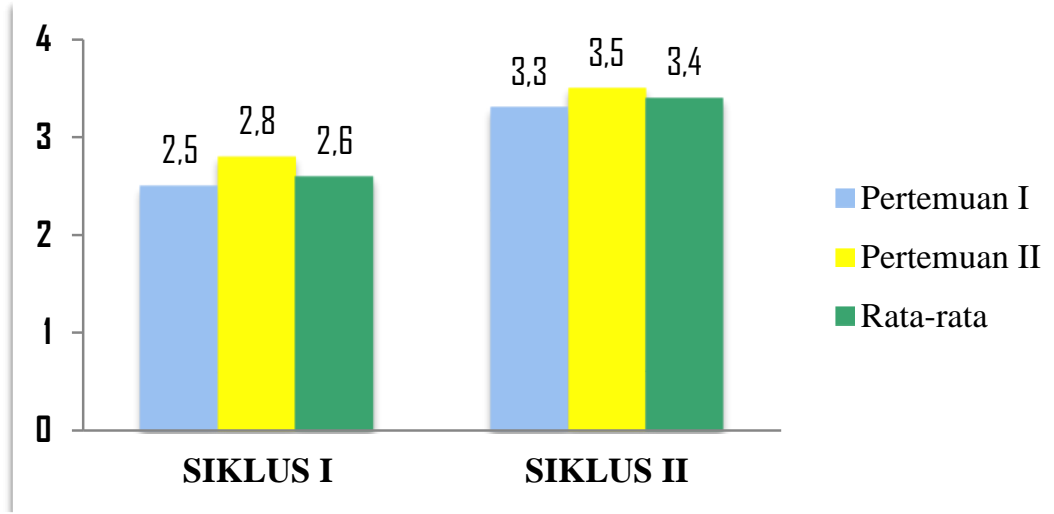

Gambar 3.1 Grafik Skor Rata-Rata Aktivitas Belajar Siswa

Grafik diatas menunjukkan skor aktivitas belajar siswa selama pembelajaran, pada siklus I aktivitas belajar siswa belum memenuhi indikator keberhasilan, dengan skor rata-rata 2,6 yang kategori Cukup, sedangkan pada siklus II skor rata-rata menjadi 3,4 yang berkategori Baik.

\section{Aktivitas Mengajar Guru Siklus II}

Berikut data hasil analisis aktivitas mengajar guru dengan menerapkan model pembelajaran Group Investigation pada siklus II.

Tabel 3.6 Data Aktivitas Mengajar Guru Siklus II

\begin{tabular}{|c|c|c|c|c|}
\hline \multirow[b]{2}{*}{ No } & \multirow[b]{2}{*}{ Aspek Yang Diamati } & \multicolumn{3}{|c|}{ Siklus II } \\
\hline & & Pert. I & Pert. II & Rata-rata \\
\hline \multicolumn{5}{|c|}{ Kegiatan awal } \\
\hline 1 & $\begin{array}{l}\text { Guru membuka pelajaran memberi salam dan doa } \\
\text { sebelum memulai pelajaran. }\end{array}$ & 4 & 4 & 4 \\
\hline 2 & Guru mengecek kehadiran siswa. & 4 & 4 & 4 \\
\hline 3 & $\begin{array}{l}\text { Guru memberikan motivasi dan apersepsi kepada } \\
\text { siswa. }\end{array}$ & 3 & 3 & 3 \\
\hline 4 & Guru menyampaikan tujuan pembelajaran. & 3 & 4 & 3,5 \\
\hline \multicolumn{5}{|c|}{ Kegiatan inti } \\
\hline 5 & $\begin{array}{l}\text { Guru menyampaikan sub topik pembelajaran yang } \\
\text { akan diselidiki }\end{array}$ & 4 & 4 & 4 \\
\hline 6 & $\begin{array}{l}\text { Guru membagi kelas dalam beberapa kelompok } \\
\text { heterogen beranggotakan } 4-5 \text { orang siswa }\end{array}$ & 4 & 4 & 4 \\
\hline 7 & $\begin{array}{l}\text { Guru membagikan LKS kepada setiap kelompok } \\
\text { kelompok serta mempersiapkan dan menata } \\
\text { sumber belajar lain sebagai sarana siswa berfantasi } \\
\text { agar dapat berinvestigasi secara optimal. }\end{array}$ & 4 & 4 & 4 \\
\hline
\end{tabular}




\begin{tabular}{|c|c|c|c|c|}
\hline 8 & $\begin{array}{l}\text { Guru memfasilitasi, membimbing serta mengawasi } \\
\text { siswa yang sedang berfantasi dan berinvestigasi } \\
\text { agar setiap kelompok dapat bekerja optimal. }\end{array}$ & 3 & 4 & 3,5 \\
\hline 9 & $\begin{array}{l}\text { Guru membimbing tiap kelompok untuk } \\
\text { mempersiapakan laporan akhir yang akan } \\
\text { dipersentasekan didepan kelas. }\end{array}$ & 4 & 4 & 4 \\
\hline 10 & $\begin{array}{l}\text { Guru meminta setiap kelompok untuk } \\
\text { mempersentasikan laporan akhir kelompoknya } \\
\text { didepan kelas dan kelompok lainnya diminta untuk } \\
\text { memperhatikan jalannya persentasi, membuat } \\
\text { rangkuman, dan/atau mengajukan pertanyaan } \\
\text { terkait topik yang disajikan. }\end{array}$ & 3 & 4 & 3,5 \\
\hline 11 & $\begin{array}{l}\text { Guru memberikan penghargaan kepada kelompok } \\
\text { yang kinerjanya bagus dan memberikan motivasi } \\
\text { pada kelompok yang kurang baik. }\end{array}$ & 3 & 3 & 3 \\
\hline 12 & $\begin{array}{l}\text { Guru memberikan penegasan terhadap masing- } \\
\text { masing bahasan dari setiap kelompok. }\end{array}$ & 3 & 4 & 3,5 \\
\hline 13 & $\begin{array}{l}\text { Guru melakukan refleksi terhadap pembelajaran } \\
\text { yang telah dipelajari. }\end{array}$ & 2 & 3 & 2,5 \\
\hline \multicolumn{5}{|c|}{ Kegiatan akhir } \\
\hline 14 & $\begin{array}{l}\text { Guru memberikan kesempatan kepada siswa untuk } \\
\text { bertanya mengenai materi yang kurang dimengerti }\end{array}$ & 3 & 4 & 3,5 \\
\hline 15 & $\begin{array}{l}\text { Guru bersama siswa menyimpulkan materi yang } \\
\text { telah dibahas }\end{array}$ & 4 & 4 & 4 \\
\hline 16 & $\begin{array}{l}\text { Guru memberi tugas kepada siswa terkait dengan } \\
\text { materi yang sudah dipelajari }\end{array}$ & 3 & 3 & 3 \\
\hline 17 & $\begin{array}{l}\text { Guru menyampaikan bahwa pada } \\
\text { pertemuberikutnya masih menggunakan metode } \\
\text { yang sama }\end{array}$ & 3 & 3 & 3 \\
\hline 18 & $\begin{array}{l}\text { Guru menutup kegiatan pembelajaran dengan } \\
\text { salam }\end{array}$ & 4 & 4 & 4 \\
\hline & Rata Rata Aktivitas Mengajar Guru & 3.4 & 3,7 & 3.6 \\
\hline
\end{tabular}

Sumber: Analisis Data (2017)

Berdasarkan data pada tabel 3.6 terlihat bahwa skor rata-rata aktivitas mengajar guru pada siklus II menunjukkan peningkatan yang signifikan dari siklus sebelumnya, hal ini terlihat dari skor ratarata aktivitas mengajar guru yang mencapai 3,6 dengan kategori Baik.

Gambaran peningkatan skor ratarata aktivitas guru pada setiap siklus dalam mengelolah pembelajaran dengan menggunakan model Pembelajaran Kooperatif tipe Group Investigation yang diperoleh dengan menggunakan lembar observasi aktivitas guru dapat dilihat pada gambar 3.2 berikut: 
Jurnal Penelitian Pendidikan Geografi Volume 3 No. 3 Juli 2018

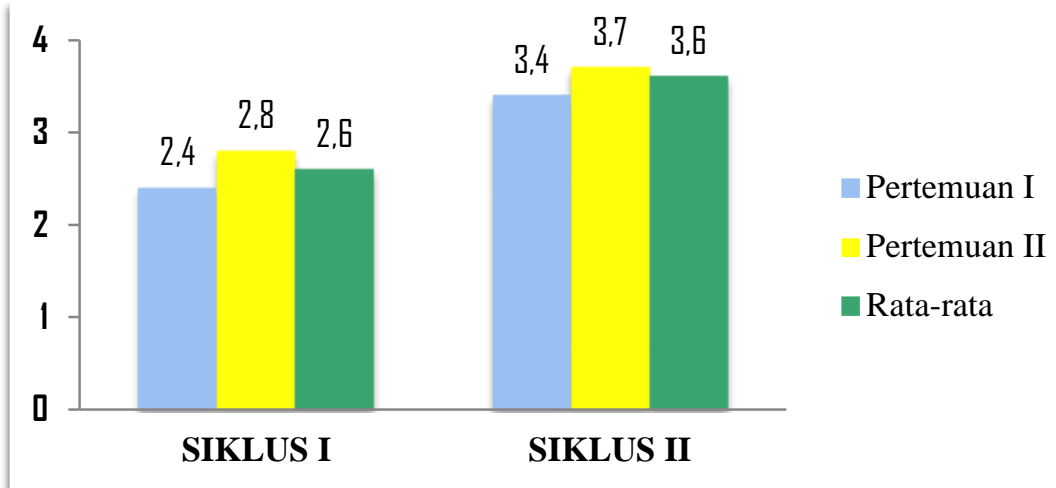

Gambar 3.2 Grafik Skor Rata-Rata Aktivitas Mengajar Guru

Grafik diatas menunjukkan skor aktivitas mengajar guru selama pembelajaran, pada siklus I aktivitas mengajar guru belum memenuhi indikator keberhasilan, dengan skor rata-rata 2,6 yang kategori Cukup, sedangkan pada siklus II skor rata-rata menjadi 3,6 yang berkategori

Baik.

Hasil Belajar Siswa Siklus II

Berdasarkan analisis hasil belajar siswa pada siklus II diperoleh data sebagai berikut:

Tabel 3.7 Perolehan Nilai Hasil Belajar Siswa Pada Siklus II

\begin{tabular}{lc}
\hline \multicolumn{1}{c}{ Hasil Belajar } & Nilai \\
\hline Nilai Tertinggi & 96 \\
\hline Nilai Terendah & 52 \\
\hline Rata-rata & 80,27 \\
\hline
\end{tabular}

Sumber: Analisis Data (2017)

Tabel 3.7 diatas menunjukkan hasil belajar siswa kelas XI IPS pada siklus II yang diajar dengan menggunakan model pembelajaran Group Investigation dengan perolehan nilai tertinggi sebesar 96, nilai terendah 52, dan nilai rata-rata 80,27.
Selanjutnya data dianalisis berdasarkan ketuntasan belajar siswa, dengan hasil sebagai berikut

Tabel 3.8 Deskripsi Ketuntasan Belajar Siswa Siklus II

\begin{tabular}{lcc}
\hline \multicolumn{1}{c}{ Ketuntasan } & Jumlah Siswa (orang) & Persentase (\%) \\
\hline Sudah Tuntas & 25 & 83 \\
\hline Belum Tuntas & 5 & 17 \\
\hline Jumlah & $\mathbf{3 0}$ & $\mathbf{1 0 0}$
\end{tabular}

Sumber: Analisis Data (2017)

Tabel 3.8 diatas menunjukkan ketuntasan belajar siswa pada siklus II, dengan siswa yang memperoleh nilai ketuntasan sebanyak 25 orang atau sekitar $83 \%$, dan siswa yang belum memperoleh nilai ketuntasan sebanyak 5 orang atau sekitar $17 \%$.
Untuk lebih jelasnya mengenai gambaran hasil belajar siswa kelas XI IPS SMA Negeri 2 Wawotobi yang diajar dengan menggunakan model pembelajaran Kooperatif tipe Group Investigation pada siklus I dan siklus II dapat dilihat pada gambar berikut: 


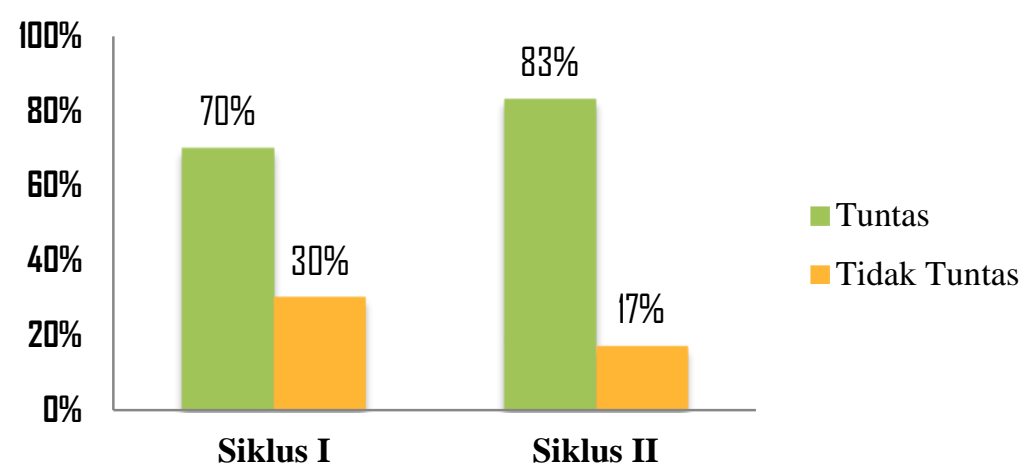

Gambar 3.3 Grafik Persentase Ketuntasan Hasil Belajar Siswa

\begin{abstract}
Grafik diatas menunjukkan perbandingan ketuntasan hasil belajar Geografi siswa pada setiap siklus. Pada siklus I persentase ketuntasan hasil belajar siswa sebesar $70 \%$ dengan skor rata-rata 74,27 , sedangkan pada siklus II mengalami peningkatan persentase sebesar $13 \%$, menjadi $83 \%$ dengan skor rata-rata 80,27.
\end{abstract}

\section{PEMBAHASAN}

\section{Aktivitas Belajar Siswa}

Pada hasil pengamatan yang disertai refleksi disetiap akhir siklus, dapat dilihat bahwa pemahaman materi dan hasil belajar siswa mengalami peningktan disetiap siklusnya. Hal ini disebabkan oleh model pembelajaran Group Investigation yang melibatkan aktivitas siswa ketika mempelajari materi dalam pembelajaran. Siswa juga dilibatkan secara penuh dalam proses belajar. Tugas, belajar berinteraksi dengan teman satu kelompok, belajar dengan berdiskusi, belajar mengaitkan materi dengan kehidupan, motivasi yang kuat, dan refleksi diri adalah bagian dari model pembelajaran Group Investigation yang berperan dalam pembelajaran yang dilakukan oleh siswa.

Pada pelaksanaan siklus I masih ada siswa yang datang terlambat, siswa yang tidak mencatat materi penting yang disampaikan oleh guru, kurang tertib saat pembagian kelompok, kurang kompak memecahkan masalah dalam LKS, bahkan beberapa dari mereka masih ada yang bermain, serta ada juga siswa yang tidak memahami jawaban dari pertanyaan dalam LKS. Sehingga jalannya proses belajar mengajar belum berjalan secara optimal sesuai yang diharapkan. Siswa juga kurang berani bertanya kepada guru mengenai materi yang kurang dipahami dan juga tampak enggan untuk mempresentasikan hasil diskusi di depan kelas. Selain itu Masih banyak siswa yang kurang fokus dalam menyimpulkan materi pembelajaran sehingga hanya beberapa siswa saja yang melakukannya.

Setelah dilakukan refleksi pelaksanaan siklus II terdapat beberapa perubahan yang baik, seperti siswa lebih sigap dalam membentuk kelompok, sehingga pada siklus II pelajaran segera dimulai tanpa meributkan masalah pembentukan kelompok, siswa lebih serius mengadakan diskusi dengan kelompoknya untuk memecahkan masalah dalam LKS, dan siswa juga sudah tidak takut lagi dalam bertanya maupun mengemukakan pendapatnya, baik pada sesama siswa ataupun kepada guru.

Berdasarkan rekapitulasi aktivitas belajar siswa secara keseluruhan terjadi peningkatan yang signifikan dari siklus I ke siklus II, pada siklus I skor rata-ratanya yakni 2,6 dengan kategori cukup, sedangkan pada siklus II skor rata-ratanya meningkat menjadi 3,4 dengan kategori baik. Hasil tersebut menunjukan bahwa penelitian pada aspek aktivitas belajar siswa dapat dikatakan berhasil karena telah memenuhi standar minimal aktivitas belajar siswa yaitu 3,0.

\section{Aktivitas Mengajar Guru}

Hasil pengamatan aktivitas guru pada siklus I menunjukkan, guru belum maksimal dalam mengadakan pembelajaran dengan 
menerapkan model pembelajaran Group Investigation. Hal ini dikarenakan guru belum terbiasa melakukan model pembelajaran Group Investigation. Guru juga masih kurang tegas dalam menghadapi siswa di kelas. Maka dari itu terdapat beberapa aspek aktivitas guru yang perlu diperbaiki dan ditingkatkan lagi, termasuk memotivasi siswa pada awal pertemuan dan melakukan refleksi terhadap pembelajaran yang dilakukan.

Untuk tindakan dalam siklus II ini dilakukan perbaikan skenario pembelajaran berdasarkan hasil refleksi dan evaluasi pada siklus I. Pada siklus II kegiatan pembelajaran dengan model pembelajaran Group Investigation sudah berjalan dengan semestinya sehingga menunjukkan hasil yang baik. Selama berlangsungnya kegiatan di siklus II kekurangan-kerurangan yang ada di siklus I sudah bisa teratasi. Baik siswa maupun guru telah menunjukkan peningkatan. Hal ini juga dikarenakan siswa dan guru sudah terbiasa dengan model pembelajaran yang diterapkan. Selain itu guru lebih mempersiapkan diri secara maksimal, lebih tegas lagi kepada siswanya, sehingga pada siklus II pelaksanaan tindakan pembelajaran yang diterapkan telah sesuai.

Berdasarkan rekapitulasi aktivitas mengajar guru secara keseluruhan terjadi peningkatan dari siklus I ke siklus II, siklus I masih dalam kategori cukup dengan rata-rata 2,6. Setelah melakukan refleksi serta perbaikan, pada siklus II skor aktivitas mengajar guru meningkat dengan rata-rata 3,6 yang berkategori baik. Hasil tersebut menunjukan bahwa penelitian pada aspek aktivitas mengajar guru dapat dikatakan berhasil karena telah memenuhi standar minimal aktivitas guru yaitu 3,0.

\section{Hasil Belajar Siswa}

Siklus I dengan penerapan model pembelajaran kooperatif tipe Group Investigation, siswa yang mencapai Kriteria Ketuntasan Minimal (KKM) 70 sebanyak 21 siswa atau sekitar $70 \%$, dimana ketuntasan hasil belajar geografi pada siklus I belum mencapai indikator keberhasil yaitu $80 \%$ dan masih ada 9 siswa yang nilainya $<70$ atau sekitar $30 \%$. Nilai rata-rata siswa 74,27 sedangkan nilai tertinggi adalah 92 dan nilai terendah adalah 40. Pelaksanaan pembelajaran yang dilakukan pada siklus I sudah terlaksana cukup baik walaupun masih ada siswa yang nilainya belum tuntas, setelah diselidiki melalui observasi, siswa yang nilainya rendah tersebut saat pembelajaran berlangsung tidak fokus, sehingga tidak menyimak apa yang disampaikan guru, juga pada saat guru memberikan tugas, ada yang tidak aktif mengerjakan tugas kelompoknya, selain itu ada juga yang tidak hadir pada saat pertemuan pertama atau pertemuan kedua yang menyebabkan siswa tersebut ketinggalan materi pembelajaran, sehingga saat melakukan evaluasi pada siklus I masih ada beberapa siswa yang tidak menjawab pertanyaan dengan baik.

Setelah melakukan evaluasi dan analisis hasil belajar siswa yang secara klasikal belum mencapai ketuntasan, maka peneliti, guru geografi dan observer bersamasama merefleksi kekurangan dan melakukan perbaikan untuk diaplikasikan pada siklus berikutnya.

Pelaksanaan siklus II dilakukan tindakan berdasarkan hasil refleksi dan evaluasi pada siklus I, terdapat beberapa perubahan yang baik, seperti guru yang sudah lebih tegas kepada siswa, yang menyebabkan siswa menyimak dengan baik dan tertib, serta siswa yang lebih serius melakukan diskusi dengan kelompoknya. Siswa yang mencapai Kriteria Ketuntasan Minimal (KKM) 70 sebanyak 25 siswa atau sekitar $83 \%$, dan yang belum mencapai nilai ketuntasan sebanyak 5 siswa atau sekitar $17 \%$. Nilai rata-rata siswa 80,27 sedangkan nilai tertinggi adalah 96 dan nilai terendah adalah 52. Sehingga dapat disimpulkan bahwa hasil belajar pada siklus II ini secara klasikal dikatakan berhasil karena persentase ketuntasan belajar siswa $>80 \%$.

Melihat hasil siklus II tersebut, maka hipotesis tindakan dan indikator keberhasilan telah tercapai sehingga tidak perlu dilakukan siklus berikutnya. Dengan demikian, jawaban atas permasalahan dalam penelitian telah terpecahkan yaitu pembelajaran dengan menerapkan model pembelajaran kooperatif tipe Group Investigation berhasil 
meningkatkan aktivitas belajar siswa, aktivitas mengajar guru, dan hasil belajar geografi siswa kelas XI IPS SMA Negeri 2 Wawotobi pada materi pokok Sumber Daya Alam.

\section{KESIMPULAN}

Berdasarkan hasil penelitian pada pembahasan sebelumnya dapat ditarik kesimpulan sebagai berikut : 1) Aktivitas belajar siswa dalam pembelajaran geografi yang diajar dengan menerapkan model pembelajaran Group Investigation menunjukan peningkatan yang baik dari siklus I ke siklus II, dimana diperoleh skor rata-rata pada siklus I yakni 2,6 yang berkategori cukup, dan meningkat menjadi 3,4 pada siklus II dengan kategori baik. 2) Aktivitas mengajar guru yang menerapkan model pembelajaran Group Investigation juga menunjukkan adanya peningkatan yang signifikan, dimana skor rata-rata aktivitas mengajar guru pada silkus I yakni 2,6 dengan kategori cukup, meningkat menjadi 3,6 pada siklus II dengan kategori baik.3) Hasil belajar Geografi siswa kelas XI IPS SMA Negeri 2 Wawotobi pada materi pokok Sumber Daya Alam dapat ditingkatkan melalui model pembelajaran kooperaif tipe Group Investigation. Hal ini dapat dilihat dari peningkatan nilai rata-rata dan persentase ketuntasan hasil belajar siswa. Dimana pada siklus I dari 30 orang siswa terdapat 21 orang yang mencapai ketuntasan atau sebanyak $70 \%$ yang mencapai nilai $\geq$ 70 sesuai $\mathrm{KKM}$ yang ditetapkan dengan nilai rata-rata 74,27 dan pada siklus II mengalami peningkatan menjadi $83 \%$ atau sebanyak 25 orang yang mendapatkan nilai $\geq 70$ dengan nilai rata-rata 80,27 .

\section{DAFTAR PUSTAKA}

Dimyati., Mudjiono. 2006. Belajar dan Pembelajaran. Jakarta: PT Rineka Cipta.

Hamalik, Oemar. 2009. Proses Belajar Mengajar. Bandung: PT Bumi Aksara.
Harisantoso, John. 2005. Pendekatan Kooperatif Model Group Investigation Suatu Analisis Pengantar Edusaintek. Vol 1, No 1, Hal 1-8, Edusaintek.

Harmanto, Gatot. 2008. Geografi Bilingual untuk SMA/MA Kelas X. Bandung: Yrama Widya.

Ibrahim, M. 2000. Pembelajaran Kooperatif. Surabaya: University Press.

Khosim., Lubis. 2007. Geografi Untuk SMA Kelas X. Jakarta : Gramedia.

Mardewanti, Endah. 2016. Pengembangan Perangkat Pembelajaran dengan Pendekatan CTL Menggunakan Model Kooperatif Group Investigation untuk Melatihkan Keterampilan Berpikir Kritis Siswa SMA Pada Materi Fluida Statis. Vol. 6, No. 1, Pendidikan Sains Pascasarjana Universitas Negeri Surabaya.

Nurhadi, dkk. 2004. Pembelajaran Kontekstual dan Penerapannya dalam KBK. Malang: UM Press.

Putra. 2009. Model Pembelajaran Kooperatif Tipe Group Investigation. Jakarta : Bumi Aksara.

Ratnasari, Mita. 2016. Efektifitas Hasil Geografi Materi Sumber Daya Alam (SDA) Menggunakan Model Pembelajaran Kooperatif Tipe Group Investigation (GI), Student Teams Achievement Divisions (STAD), dan Ceramah pada Siswa Kelas XI IPS SMA Negeri 1 Ponorogo. Vol. 2, No. 1, Hal. 49-59, Jurnal GeoEco

Rifa'I, Ahmad., Anti Tri. 2009. Psikologi Pendidikan. Semarang Universitas Negeri Semarang Press. 
Jurnal Penelitian Pendidikan Geografi Volume 3 No. 2 April 2018

Sanjaya, Wina. 2010. Strategi Pembelajaran

Berorientasi Standar Proses

Pendidikan. Jakarta: Kencana.

Slameto, 2003. Belajar dan Faktor-Faktor yang Mempengaruhi. Jakarta : PT Rineka Cipta.

Sudjana. 2005. Metoda Statistika. Bandung: Tarsito.

Susetyo, B. 2010. Statistka untuk analisis data penelitian. Bandung : Refika Ditama.

Suyanto., Hisyam, Djihad. 2000. Refleksi dan Reformasi Pendidikan Indonesia Memasuki Milenium III. Yogyakarta: Adi Cita.

Trianto, 2010. Mengembangkan Model Pembelajaran Tematik, Jakarta: PT Prestasi Pustaka.

Usman., Setiawati. 2001. Statistika. Bandung: Remaja Rosdakarya.

Yamin, Martinis. 2007. Profesionalisasi Guru \& Implementasi KTSP. Jakarta: Gaung Persada Press. 